\title{
IAMJ
}

INTERNATIONAL

AYURVEDIC

MEDICAL JOURNAL

\section{AN ATTEMPT TO UNDERSTAND THE CLINICAL APPROACH OF ADRAVYABHUTA CHIKITSA}

\section{$\underline{\text { Shridharaiah M.H' }}^{\mathbf{1}}, \underline{\text { P.V Joshi }}^{\mathbf{2}}$}

${ }^{1}$ BAMS, $2^{\text {nd }}$ year P.G Scholar, Department of PG Studies in Kayachikitsa, Shri Vijaya Mahantesh Ayurvedic Medical college \& P.G Research Centre, Ilkal, Karnataka, India

${ }^{2}$ BAMS MD (Ayu), Professor \& HOD, Department of PG Studies in Kayachikitsa, Shri Vijaya Mahantesh Ayurvedic Medical College \& P.G Research Centre, Ilkal, Karnataka, India

Corresponding Author: shridharhiremath143@gmail.com

https://doi.org/10.46607/iamj1609122021

(Published Online: December 2021)

Open Access

(C) International Ayurvedic Medical Journal, India

Article Received: 04/11//2021 - Peer Reviewed: 27/11/2021 - Accepted for Publication 15/12/2021

\section{Check for updates}

\section{ABSTRACT}

Chikitsa (Treatment protocols) is Pravrutti (effort) made by Gunayukta Chikitsa Chatuspada (Physician, nurse, medications and patient) to bring back Dhatu Samyata (Healthy state) whenever there is Dhatu Vaikruti (Disease state). In Ayurvedic text, we got an explanation of many types of Chikitsa for different Vyadhis (Disease) or in different Avastha (Stages) of the Vyadhi. Among all these Chikitsa, we use Dravyabhuta Chikitsa (Dimensional things) like all medication including shodhana (Purification) and shamana (Pacification) broadly but the use of the Adravyabhuta Chikitsa (Non-dimensional) is very limited. Adravyabhuta is a type of Chikitsa that is classified based on the swarupa (Shape), these Adravyabhutas Chikitsa specially deals with non - dimensional things. This review article is explaining about concept and types of Adravyabhuta Chikitsa with classical examples which our Acharyas explained in Samhitas.

Keywords: Chikitsa, Dravyabhuta, Adravyabhuta, Murta Bhava, Amurtha Bhava, Samavayi Karana. 


\section{INTRODUCTION}

Ayurveda aims to preserve health status and treat the diseased condition. ${ }^{[1]}$ To achieve this aim, different Chikitsa Vidhanas (treatment procedures) are explained in our classical text. Many of these Chikitsa Vidhana are directly acts over the Sharira and bring Dhatu Samyata i.e., Nidanaparivarjana, Santarpana, Apatarpana, Shodhana, Shamana, Rasayanaand Vajikarana are acts over the Sharira directly.

With the help of Dravyabhutas Chikitsa, we can achieve Dhatu and Dosha Samyata which get Vikruti by Sharirika Hetu (Ahara \& vihara) and can achieve victory over somatic diseases, for examples Pushkaramula in Shwasa, Kutaja in Atisara, Guduchi in Jwara but by getting only physical health is not considered as the Swastha (Healthy). For the person to be called Swastha, he should be healthy physically as well as mentally otherwise person is considered to be a diseased one ${ }^{[2]}$. Hence to fulfil the definition of Swastha Mana should be treated.

Dravyabhuta Chikitsa helps it achieve victory over Sharirika Vyadhi which developed due to Sharirika
Hetu but these Chikitsa not much beneficial over some Manasika Vikara and Shariro Manasika Vikara (Psychosomatic), so Charaka explained one separate category of Chikitsa (treatment procedure) based on Swarupa (Shape) or Angabheda called Dravyabhuta and Adravyabhuta Chikitsa, ${ }^{[3]}$ here the Dravyabhuta Chikitsa acts over the Sharira or Sharirika Hetu, but Adravyabhuta Chikitsa acts over the Manasika Vyadhi, Manasika Hetus and brings Dhatu Samyata in the patient.

Implementation of the different types of the Adravyabhuta Chikitsa over the patient depends on the Yukti of the Vaidya or Paricharaka, hence these are mainly termed as Upayas (Plans) rather than Chikitsa.

\section{DESCRIPTION}

In short, we can explain the Adravyabhuta Chikitsa as the Upayas which helps to bring back the Dhatu Samyata in a patient, these Upayas are 10 in the number listed in table no $1^{[4]}$

\section{Table No 1}

\begin{tabular}{|l|l|l|l|}
\hline 1. & Bhaya Darshana & 6. & Bharstana \\
\hline 2. & Vismaapana & 7. & Vadha \\
\hline 3. & Vismarana & 8. & Bandha \\
\hline 4. & Kshobhana & 9. & Svapna \\
\hline 5. & Harshana & 10. & Samvahana \\
\hline
\end{tabular}

\section{Bhayadarshana}

In this Chikitsa Vidhana, Bhaya (fear) is induced to the patient to get Dhatu Samyata, here fear of physical hurt is less effective compared to the fear of death, ${ }^{[5]}$ because each person in the world is much afraid of death, so much fear should be induced inpatient to bring normalcy of health.

Classically we can find some examples for Bhayadharshana $^{[6]}$
A. Terrifying patient by biting with fangless snakes.
B. A sudden encounter with a lion, elephant or oth- er such wild animals.
C. Threatening by criminals or patient's enemies who holding weapons.

Bhayadarshana is indicated in the disease Unmada.

\section{Vismapana}

Vismapana is nothing but making the person mesmerize or creating surprise.

Example - In Unmada Rogi Vismapana (surprising) helps to get Prakruta Avasta (pleasant state) of Ma$n a .^{[7]}$

\section{Vismarana}

The word Vismarana means forgetting, as the word says it is the Chikitsa which makes the person forget any previous bad incidences which causing the $M a$ nasika Vikara or making the person forget the time in which Vega of some Vyadhi like Jwara is occurring. 
Example - while explaining the Unamada Chikitsa major of the Adravyabhuta Chikitsa has been mentioned like Vadha, Bandhana, Avarodhana (Isolation in a dark room), Vitrasana, Vismarana. ${ }^{[8]}$

\section{Kshobhana}

The word Kshobhana means shaking, agitating, disturbing or causing emotional stress. It is the procedure, where emotions (anger, grief, sorrow etc...) of the patient is used as the Chikitsa by making him emotional.

Example - In Kaphaja Unmada Kshobhana is indicated as the patient is already in depression.

\section{Harshana}

The word Harshana means causing pleasure, it is the Chikitsa in which the patient is made or kept in a happy mood so that he overcome his psychological factors, here the mental stress of the patient is alleviated with the help of sudden excitement and recreational acts and ideas.

Example -

$\checkmark$ Harshana explained in Atisara Chikitsa Adhyaya of Charaka Chikitsa Sthana i.e., by the Bhaya and Shoka the Vata get Prakupita and develops the Bhayaja or Shokaja Atisara, in this condition, it is better to go for Adravyabhuta Chikitsa like Harshana and Ashwasana. ${ }^{[9]}$

$\checkmark$ In Jwara Chikitsa Harshana Chikitsa has been explained, and it is specially indicated in Kaama, Shoka and Bhayaja Jwara. ${ }^{[\mathbf{1 0}]}$

$\checkmark$ Harshana and Ashwasana Chikitsa should be done daily in the case of Rajayakshama patients. ${ }^{[11]}$

$\checkmark$ Mano Anukula Vaak (Pleasent words), Ashwasana and Harshana Chikitsa are indicated in Mano Abhighataja Chardhi. ${ }^{[12]}$

$\checkmark$ In Mano Vighata Aruchi, Harshana and Ashwashana should be done. ${ }^{[13]}$

$\checkmark$ In Madatyaya Rogi Harshana Kriya is beneficial. $^{[14]}$

\section{Barthsana}

The word Barthsana means threatening, reviling, menace, reproach, abuse or a curse and this Chikitsa is a sort of condemning act or threatening for the patient.
Examples -

$\checkmark$ In Unmada Tarjana, Trasana \& Vitrasana are indicated. ${ }^{[15]}$

$\checkmark$ Patients with Hikka should be treated by Trasana or by Suchi Toda (Pricking with a needle). ${ }^{[16]}$

\section{Vadha}

The word Vadha means killing, murder, slaughter, destruction, frustration, blow or stroke and this Upaya is used by threatening murder or hurt to the patient.

Example - Patient is taken out of the town or village and threatened by saying, the king ordered to kill you. Or he should be threatened by his enemies who holding weapons. ${ }^{[17]}$ Vadha is indicated in Unamada Chikits.

\section{Bandha}

The word means suppression or binding, here the patient is bound and kept in an isolated room

Example - Patient is gently tied with cloth or thread and kept in the darkroom which is devoid of sharp things made of Loha (Metal), Kashta (Wood) etc...

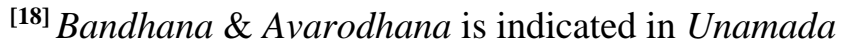
Chikits.

\section{Svapna}

Svapna is the synonym of Nidra, in Ashtanga Hridaya Arunadatta Teeka ${ }^{[19]}$, a night of sound sleep is precursor of positive health

Example - In Rasashesha Ajeeran, Diwasvapna is indicated as the Chikitsa. ${ }^{[20]}$

\section{Samvahana}

In Ashtanga hridaya Sarvangasundara and Ayurvedarasayana Teeka explained that doing mild body massage or gentle rubbing or gentle touch is called samvahana. ${ }^{[21]}$

Here we can understand that Samvahana is the treatment plan in which the physician touches the patient gently and console them with good wordings (Ashwasana) is called Samvahana Chikitsa.

Example - Svapna and Samvahana Chikitsa is beneficial in Moha, Akshi Gaurava, Shira Gaurava, Alasya, Jrumba, Angamardha developed as a result of Nidra Nigraha. ${ }^{[22]}$ 


\section{DISCUSSION}

Bhayadarshanadi (Adravyabhuta Chikitsa) implementing over the Rogi (Patients) are Amurta Bhaavas (Non-dimensional thing), even though they help in getting Swastha. But it is confusing how exactly this Adravyabhuta Chikitsa helps in getting Samyata in Vatadi Dosha \& dhatu, because all these Amurtha Bhaava are not having any Samavayi Karana (inherent cause) information of the Sharira Dravya (body elements).

Aushadhies (Medications) which we are using to treat different Vyadhis are usually Dravyabhutas (Dimensional things), these Dravyas (Substance) are having Samavayi Karana in the Samyak Utpatti (healthy origin) of Dhatus (Body elements), and it becomes logical in obtaining the Dhatu Samyata.

Adravyabhuta Chikitsa is not having Samavayi Kara$n a$ in the Utpatti of Dhatus, then also they act just similar to Dravyabhuta Chikitsa and forms Samyak Utpatti of Dhatu, this action is due to Prabhava or Parinama (effect) of these Upayas. ${ }^{[23]}$

While classifying Dravya; Karya Dravyas are explained, i.e., Akasha, Vayu, Agni, Jala, Prutvi, Aatma, Mana, Kaala and Dik ${ }^{[24]}$ are all come under Dravyas, hence all Aushadhies which we use as the Chikitsa are all becomes Dravya as they formed of Panchamahabhuta, so all Aushadhi become Dravyabhutachikitsa. Even if we take Atapa Sevana, Sheeta Vayu Samshparsha etc... as Chikitsa, then also they come under Dravyabhuta only, because of direct involvement of Dravyas like Vayu, Agni which is already told as the Dravya.

In Dravyabhuta Chikitsa we can analyze the involvement of the Guna (Qualities), Karma (Action) in treating the vyadhi and can explain the Phala Shruti (Outcome) of this Chikitsa. But in Adravyabhuta Chikitsa we can't analyze the exact involvement of Guna and Karma, which acts over the person to make him healthy and Phala Shruti of the Adravyabhuta Chikitsa is unexplainable.

After all these discussions once again confusion starts that how exactly these Amurtha Bhavas acts over Manas which is dravya (Murthabhava)? Here we can say that among all 9 Karya Dravyas if we do further classification as Murtha Dravya (Dimensional Substance) and Amurtha Dravya (Non-dimensional substances), Mana and Akasha Dravya are much more Amurtha compared to the remaining 7 Dravya. Even though the Mana is having Karya Karana Sambanda in its function but some of the dimension of Mana is unrecognizable hence Amurtha Bhavas acts over the Mana and helps in achieving health.

\section{CONCLUSION}

By all above mention discussion points, it is very important to understand the differentiation between Dravyabhuta and Adravyabhuta Chikitsa. Not only understanding, but one should use this Adravyabhuta Chikitsa to achieve patient's health.

Knowingly or unknowingly each physician in the world is using some Adravyabhuta Chikitsa in their practice life, like Ashwasana, Swapna and Samvahana. If the physician understands the concept of Adhravyabhuta Chkitsa and uses them along with Aptopadesha (Classical texts) and Yukti (Intellect) then it becomes a major tool to treat the many psychological and psychosomatic diseases easily.

\section{REFERENCES}

1. Agnivesha. CHARAKA SAMHITA (Ayurveda Dipika's Ayushi Hindi - Commentary). Vd. Harish Chandra Singh Kushwaha (Edt and Translator). First Part. Chaukhambha Orientalia Varanasi. Reprint Edition 2018. Sutra Sthana 30/26. Pg 495.

2. Sri Dallanacharya Evam Sri Gayadasavirachita. SUSHRUT SAMHITA Hindi vyaakhya. Dr. Kevala Krushna Takaral Translator. $1^{\text {st }}$ part. Chowkanmba Orientalia. Varanasi. Edition reprint 2017, Sutra Sthana 15/41. Pg. 179.

3. Agnivesha. CHARAKA SAMHITA (Ayurveda Dipika's Ayushi Hindi - Commentary). Vd. Harish Chandra Singh Kushwaha (Edt and Translator). First Part. Chaukhambha Orientalia Varanasi. Reprint Edition 2018. Vimana Sthana 8/87. Pg 683.

4. Agnivesha. CHARAKA SAMHITA (Ayurveda Dipika's Ayushi Hindi - Commentary). Vd. Harish Chandra Singh Kushwaha (Edt and Translator). First Part. Chaukhambha Orientalia Varanasi. Reprint Edition 2018. Vimana Sthana 8/87. Pg 683.

5. Agnivesha. CHARAKA SAMHITA (Ayurveda Dipika's Ayushi Hindi - Commentary). Vd. Harish Chandra Singh Kushwaha (Edt and Translator). Sec- 
ond Part. Chaukhambha Orientalia Varanasi. Reprint Edition 2018. ChikitsaSthana 9/84. Pg. 261-262.

6. Agnivesha. CHARAKA SAMHITA (Ayurveda Dipika's Ayushi Hindi - Commentary). Vd. Harish Chandra Singh Kushwaha (Edt and Translator). Second Part. Chaukhambha Orientalia Varanasi. Reprint Edition 2018. ChikitsaSthana 9/82. Pg. 261-262.

7. Agnivesha. CHARAKA SAMHITA (Ayurveda Dipika's Ayushi Hindi - Commentary). Vd. Harish Chandra Singh Kushwaha (Edt and Translator). Second Part. Chaukhambha Orientalia Varanasi. Reprint Edition 2018. ChikitsaSthana 9/31. Pg. 253.

8. Agnivesha. CHARAKA SAMHITA (Ayurveda Dipika's Ayushi Hindi - Commentary). Vd. Harish Chandra Singh Kushwaha (Edt and Translator). First Part. Chaukhambha Orientalia Varanasi. Reprint Edition 2018. NidanaSthana 7/8. Pg 573.

9. Agnivesha. CHARAKA SAMHITA (Ayurveda Dipika's Ayushi Hindi - Commentary). Vd. Harish Chandra Singh Kushwaha (Edt and Translator). Second Part. Chaukhambha Orientalia Varanasi. Reprint Edition 2018. ChikitsaSthana 19/12. Pg. 504.

10. Agnivesha. CHARAKA SAMHITA (Ayurveda Dipika's Ayushi Hindi - Commentary). Vd. Harish Chandra Singh Kushwaha (Edt and Translator). Second Part. Chaukhambha Orientalia Varanasi. Reprint Edition 2018. ChikitsaSthana 3/320-321. Pg. 135.

11. Agnivesha. CHARAKA SAMHITA (Ayurveda Dipika's Ayushi Hindi - Commentary). Vd. Harish Chandra Singh Kushwaha (Edt and Translator). Second Part. Chaukhambha Orientalia Varanasi. Reprint Edition 2018. ChikitsaSthana 8/187. Pg. 241-242.

12. Agnivesha. CHARAKA SAMHITA (Ayurveda Dipika's Ayushi Hindi - Commentary). Vd. Harish Chandra Singh Kushwaha (Edt and Translator). Second Part. Chaukhambha Orientalia Varanasi. Reprint Edition 2018. ChikitsaSthana 20/41. Pg. 531.

13. Agnivesha. CHARAKA SAMHITA (Ayurveda Dipika's Ayushi Hindi - Commentary). Vd. Harish Chandra Singh Kushwaha (Edt and Translator). Second Part. Chaukhambha Orientalia Varanasi. Reprint Edition 2018. ChikitsaSthana 26/215. Pg. 708.

14. Agnivesha. CHARAKA SAMHITA (Ayurveda Dipika's Ayushi Hindi - Commentary). Vd. Harish Chandra Singh Kushwaha (Edt and Translator). Second Part. Chaukhambha Orientalia Varanasi. Reprint Edition 2018. ChikitsaSthana 24/194. Pg. 649.

15. Agnivesha. CHARAKA SAMHITA (Ayurveda Dipika's Ayushi Hindi - Commentary). Vd. Harish Chandra Singh Kushwaha (Edt and Translator). Second Part. Chaukhambha Orientalia Varanasi. Reprint Edition 2018. ChikitsaSthana 9/31. Pg. 253.

16. Sri Dallanacharya Evam Sri Gayadasavirachita. SUSHRUT SAMHITA Hindi vyaakhya. Dr. Kevala Krushna Takaral Translator. Chowkanmba Orientalia.
Varanasi. Edition reprint 2017, Uttara tandra 50/16. Pg. 478

17. Agnivesha. CHARAKA SAMHITA (Ayurveda Dipika's Ayushi Hindi - Commentary). Vd. Harish Chandra Singh Kushwaha (Edt and Translator). Second Part. Chaukhambha Orientalia Varanasi. Reprint Edition 2018. ChikitsaSthana 9/83. Pg. 261-262.

18. Agnivesha. CHARAKA SAMHITA (Ayurveda Dipika's Ayushi Hindi - Commentary). Vd. Harish Chandra Singh Kushwaha (Edt and Translator). Second Part. Chaukhambha Orientalia Varanasi. Reprint Edition 2018. ChikitsaSthana 9/30. Pg. 253.

19. Vagbhata. ASHTANGA HRIDAYAM. With arunadatta and hemadriteeka. Collected by Dr Anna moreshwarakunte. Sanskrit. Chaukhambhaorientalia. Varanasi. Reprint tenth edition - 2019. Sutra sthana 4/12 sarvangasundarateeka. Pg. 55

20. Shrimad Vagbhata - ASTANGAHRDAYA, Nirmala Hindivyaakhya, Dr Brahmanand Tripathi (Eds) Reprint 2019, Chaukhamba Sanskrit Pratiishthana, New Delhi, Sutra Sthana 8/29-30. pg no - 140.

21. Vagbhata. ASHTANGA HRIDAYAM. With arunadatta and hemadriteeka. Collected by Dr Anna moreshwarakunte. Sanskrit. Chaukhambhaorientalia. Varanasi. Reprint tenth edition - 2019. Sutra sthana 4/12 Ayurvedarasayanateeka. Pg. 55

22. Shrimad Vagbhata - ASTANGAHRDAYA, Nirmala Hindivyaakhya, Dr Brahmanand Tripathi (Eds) Reprint 2019, Chaukhamba Sanskrit Pratiishthana, New Delhi, Sutra Sthana 4/12. pg no - 56.

23. Agnivesha. CHARAKA SAMHITA (Ayurveda Dipika's Ayushi Hindi - Commentary). Vd. Harish Chandra Singh Kushwaha (Edt and Translator). First Part. Chaukhambha Orientalia Varanasi. Reprint Edition 2018. Vimana Sthana 8/87 Chakrapani teeka. Pg.684.

24. Agnivesha. CHARAKA SAMHITA (Ayurveda Dipika's Ayushi Hindi - Commentary). Vd. Harish Chandra Singh Kushwaha (Edt and Translator). First Part. Chaukhambha Orientalia Varanasi. Reprint Edition 2018. Sutra Sthana 1/48. Pg. 18.

\section{Source of Support: Nil \\ Conflict of Interest: None Declared}

How to cite this URL: Shridharaiah M.H \& P.V Joshi: An Attempt To Understand The Clinical Approach Of Adravyabhuta Chikitsa. International Ayurvedic Medical Journal \{online\} 2021 \{cited December 2021\} Available from:

http://www.iamj.in/posts/images/upload/3021_3025.pdf 